\title{
SOUTH WEST AFRICA Suidwes-Afrika-Namibia
}

Territory under South African administration, as South West Africa, and policed by South African internal security agencies. The current Administrator-General is Dr Willen van Niekerk.

The main anti-South-African guerilla movement is the South West Africa People's Organisation (SWAPO). 